\title{
Front Matter: Volume 7337
}

, "Front Matter: Volume 7337," Proc. SPIE 7337, Algorithms for Synthetic Aperture Radar Imagery XVI, 733701 (22 May 2009); doi: 10.1117/12.834335

SPIE Event: SPIE Defense, Security, and Sensing, 2009, Orlando, Florida, United SPIE. States 


\section{PROCEEDINGS OF SPIE}

\section{Algorithms for Synthetic Aperture Radar Imagery XVI}

Edmund G. Zelnio

Frederick D. Garber

Editors

16-17 April 2009

Orlando, Florida, United States

Sponsored and Published by

SPIE

Volume 7337

Proceedings of SPIE, 0277-786X, v. 7337 
The papers included in this volume were part of the technical conference cited on the cover and title page. Papers were selected and subject to review by the editors and conference program committee. Some conference presentations may not be available for publication. The papers published in these proceedings reflect the work and thoughts of the authors and are published herein as submitted. The publisher is not responsible for the validity of the information or for any outcomes resulting from reliance thereon.

Please use the following format to cite material from this book:

Author(s), "Title of Paper," in Algorithms for Synthetic Aperture Radar Imagery XVI, edited by Edmund G. Zelnio, Frederick D. Garber, Proceedings of SPIE Vol. 7337 (SPIE, Bellingham, WA, 2009) Article CID Number.

ISSN 0277-786X

ISBN 9780819476036

Published by

SPIE

P.O. Box 10, Bellingham, Washington 98227-0010 USA

Telephone +1 3606763290 (Pacific Time) · Fax +1 3606471445

SPIE.org

Copyright (C) 2009, Society of Photo-Optical Instrumentation Engineers

Copying of material in this book for internal or personal use, or for the internal or personal use of specific clients, beyond the fair use provisions granted by the U.S. Copyright Law is authorized by SPIE subject to payment of copying fees. The Transactional Reporting Service base fee for this volume is $\$ 18.00$ per article (or portion thereof), which should be paid directly to the Copyright Clearance Center (CCC), 222 Rosewood Drive, Danvers, MA 01923. Payment may also be made electronically through CCC Online at copyright.com. Other copying for republication, resale, advertising or promotion, or any form of systematic or multiple reproduction of any material in this book is prohibited except with permission in writing from the publisher. The CCC fee code is 0277-786X/09/\$18.00.

Printed in the United States of America.

Publication of record for individual papers is online in the SPIE Digital Library.

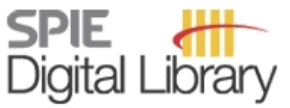

SPIEDigitalLibrary.org

Paper Numbering: Proceedings of SPIE follow an e-First publication model, with papers published first online and then in print and on CD-ROM. Papers are published as they are submitted and meet publication criteria. A unique, consistent, permanent citation identifier (CID) number is assigned to each article at the time of the first publication. Utilization of CIDs allows articles to be fully citable as soon they are published online, and connects the same identifier to all online, print, and electronic versions of the publication. SPIE uses a six-digit CID article numbering system in which:

- The first four digits correspond to the SPIE volume number.

- The last two digits indicate publication order within the volume using a Base 36 numbering system employing both numerals and letters. These two-number sets start with 00, 01, 02, 03, 04, $05,06,07,08,09,0 A, 0 B \ldots 0 Z$, followed by 10-1Z, 20-2Z, etc.

The CID number appears on each page of the manuscript. The complete citation is used on the first page, and an abbreviated version on subsequent pages. Numbers in the index correspond to the last two digits of the six-digit CID number. 


\section{Contents}

vii Conference Committee

\section{SESSION 1 ADVANCED IMAGING}

733702 Enhancement of multi-pass 3D circular SAR images using sparse reconstruction techniques [7337-01]

M. Ferrara, Air Force Research Lab. (United States); J. A. Jackson, C. Austin, The Ohio State Univ. (United States)

733703 Sparse multipass 3D SAR imaging: applications to the GOTCHA data set [7337-02]

C. D. Austin, E. Ertin, R. L. Moses, The Ohio State Univ. (United States)

733704 Surface models to constrain three-dimensional sparse SAR reconstruction [7337-05]

R. A. Weisenseel, T. Falcone, Scientific Systems Co., Inc. (United States)

733705 Compressed sensing of mono-static and multi-static SAR [7337-04]

I. Stojanovic, W. C. Karl, Boston Univ. (United States); M. Cetin, Sabanci Univ. (Turkey)

733706 SAR imaging via iterative adaptive approach and sparse Bayesian learning [7337-03] M. Xue, E. Santiago, Univ. of Florida (United States); M. Sedehi, Univ. of Rome, La Sapienza (Italy); X. Tan, J. Li, Univ. of Florida (United States)

733707 Chirp-scaling-based true amplitude imaging for synthetic aperture radar [7337-06] L. Wang, Rensselaer Polytechnic Institute (United States) and Nanjing Univ. of Aeronautics and Astronautics (China); C. E. Yarman, WesternGeco-Schlum-berger (United States);

B. Yazici, Rensselaer Polytechnic Institute (United States)

733708 High-performance synthetic aperture radar image formation on commodity multicore architectures [7337-07]

D. S. McFarlin, F. Franchetti, M. Püschel, J. M. F. Moura, Carnegie Mellon Univ. (United States)

\section{SESSION 2 MOTION AND FOCUSING}

7337 OA Considerations for autofocus of spotlight-mode SAR imagery created using a beamforming algorithm [7337-08]

C. V. Jakowatz, Jr., D. E. Wahl, Sandia National Labs. (United States)

7337 OB Minimum-entropy autofocus for three-dimensional SAR imaging [7337-09]

T. J. Kragh, BAE Systems (United States)

7337 OC A nonquadratic regularization-based technique for joint SAR imaging and model error correction [7337-10]

N. Ö. Önhon, M. Çetin, Sabanci Univ. (Turkey) 
7337 OD Exact and approximate time-shift operators [7337-11]

J. E. Piper, Naval Surface Warfare Ctr. Panama City (United States)

7337 OE Simulating the effects of long-range collection on synthetic aperture radar imagery [7337-12]

J. A. Richards, Sandia National Labs. (United States)

7337 OF Analysis of target rotation and translation in SAR imagery [7337-13]

A. R. Fasih, The Ohio State Univ. (United States); B. D. Rigling, Wright State Univ. (United

States); R. L. Moses, The Ohio State Univ. (United States)

7337 OG A challenge problem for SAR-based GMTI in urban environments [7337-14]

S. M. Scarborough, C. H. Casteel, Jr., L. Gorham, M. J. Minardi, U. K. Majumder, M. G. Judge,

E. Zelnio, M. Bryant, Air Force Research Lab. (United States); H. Nichols, D. Page, BAE Systems

(United States)

\section{SESSION 3 SAR FEATURE EXTRACTION}

$7337 \mathrm{OH}$ An algorithm for 3D target scatterer feature estimation from sparse SAR apertures [7337-15] J. A. Jackson, R. L. Moses, The Ohio State Univ. (United States)

7337 Ol Multiple feature-enhanced synthetic aperture radar imaging [7337-16] S. Samadi, Shiraz Univ. (Iran, Islamic Republic of); M. Çetin, Sabanci Univ. (Turkey); M. A. Masnadi-Shirazi, Shiraz Univ. (Iran, Islamic Republic of)

7337 OJ Localization of scattering centers in radar imaging based on sparsity constraints [7337-17] S. K. Gunnala, J. B. Hall, J. Bredow, S. Tjuatja, The Univ. of Texas at Arlington (United States)

7337 OK Independent source extraction applied to radar imaging [7337-18]

J. B. Hall, The Univ. of Texas at Arlington (United States) and Lockheed Martin Corp. (United States); S. Gunnala, S. Tjuatja, The Univ. of Texas at Arlington (United States)

$7337 \mathrm{OL}$ The spectrum parted linked image test (SPLIT) algorithm for estimating the frequency dependence of scattering center amplitudes [7337-19]

D. F. Fuller, M. A. Saville, Air Force Institute of Technology (United States)

SESSION 4 SAR ATR

7337 OM Utilizing feedback in adaptive SAR ATR systems [7337-22]

O. Horsfield, Land Engineering Agency (Australia); D. Blacknell, Defence Science and Technology Lab. (United Kingdom)

7337 ON Shadow-based SAR ATR performance prediction [7337-23]

D. Blacknell, Defence Science and Technology Lab. (United Kingdom)

$733700 \quad$ DC optimization modeling for shape-based recognition [7337-24]

K. Sturtz, Universal Mathematics (United States); G. Arnold, M. Ferrara, Air Force Research Lab. (United States) 
7337 OP Target detection and classification in SAR images using region covariance and co-difference [7337-25]

K. Duman, Bilkent Univ. (Turkey); A. Eryildirim, Meteksan Savunma Sanayii A.S. (Turkey);

A. E. Cetin, Bilkent Univ. (Turkey)

$7337 \mathrm{OQ}$ Analysis of uncompensated phase error on automatic target recognition performance [7337-26]

L. J. Montagnino, M. L. Cassabaum, S. D. Halversen, C. T. Rupp, G. M. Wagner, M. T. Young, Raytheon Missile Systems (United States)

7337 OR Classifying civilian vehicles using a wide-field circular SAR [7337-27]

K. E. Dungan, L. C. Potter, The Ohio State Univ. (United States)

7337 OS Effects of SAR image compression on coherent change detection [7337-29]

L. M. Novak, C. E. Frost, Scientific Systems Co., Inc. (United States)

Author Index 
Downloaded From: https://www.spiedigitallibrary.org/conference-proceedings-of-spie on 26 Apr 2023

Terms of Use: https://www.spiedigitallibrary.org/terms-of-use 


\section{Conference Committee}

Symposium Chair

Ray O. Johnson, Lockheed Martin Corporation (United States)

Symposium Cochair

Michael T. Eismann, Air Force Research Laboratory (United States)

Conference Chairs

Edmund G. Zelnio, Air Force Research Laboratory (United States)

Frederick D. Garber, Wright State University (United States)

Program Committee

Bir Bhanu, University of California, Riverside (United States)

Müjdat Çetin, Sabanci University (Turkey)

Dan E. Dudgeon, BAE Systems plc (United States)

Gil J. Ettinger, BAE Systems Advanced Information Technologies

(United States)

Robert A. Hummel, Booz Allen Hamilton (United States)

Charles V. Jakowatz, Jr., Sandia National Laboratory (United States)

Eric R. Keydel, Science Applications International Corporation (United States)

Randolph L. Moses, The Ohio State University (United States)

Lee C. Potter, The Ohio State University (United States)

Brian D. Rigling, Wright State University (United States)

Timothy D. Ross, Air Force Research Laboratory (United States)

Gerard W. Titi, BAE Systems Advanced Information Technologies (United States)

Stephen Welby, Consutant (United States)

Session Chairs

1 Advanced Imaging

Lee C. Potter, The Ohio State University (United States)

2 Motion and Focusing

Charles V. Jakowatz, Jr., Sandia National Laboratory (United States)

3 SAR Feature Extraction

Gerard W. Titi, BAE Systems (United States) 
SAR ATR

Edmund G. Zelnio, Air Force Research Laboratory (United States) 